\title{
Program Partnerstwa Publicznego nową formą współpracy jednostek sektora finansów publicznych
}

\section{Wprowadzenie}

Zapewnienie właściwego źródła finansowania choćby części zadań wykonywanych przez administrację publiczną jest zagadnieniem niezwykle istotnym, zwłaszcza biorąc pod uwagę wiele zadań, które muszą być wykonywane permanentnie, a także tych, które częstokroć mimo ich wagi nie są realizowane ze względu na ich szczególną specyfikę, wieloaspektowość, stopień złożenia czy wysoką kosztochłonność, co przesuwa ich realizację na okres późniejszy, a trwa to niejednokrotnie przez całe dekady. Zagadnienia owe stają się też głównie przedmiotem działań organizacji pozarządowych i fascynatów, których z czasem traktuje się bardziej jak nieszkodliwych hobbystów niż ludzi, instytucje czy inne podmioty mówiące o istotnych dziedzinach życia państwa, mogących generować ważne dochody budżetowe i liczne miejsca pracy, jak np. gospodarka wodna, o żegludze śródlądowej już nie wspominając ${ }^{1}$.

Odrębny problem stanowi sposób dysponowania posiadanymi środkami, uwzględniający specyfikę dziedziny, a zwłaszcza wielopodmiotowość podejmowanych przedsięwzięć oraz ich różnorodność. Jest to istotne zwłaszcza w dziedzinach wymagających wielu niekonwencjonalnych czy specyficznych działań i przedsięwzięć, co oznacza, że w szczególny sposób ich realizacja jest zagrożona na gruncie standardowej gospodarki budżetowej. Działaniom takim nie służą niejasne procedury, a jeszcze bardziej niejasna czy wręcz ,zaskakująca” ich interpretacja. Nie sprzyja to podejmowaniu przez administrację ważnych decyzji i działań, często o charakterze wieloletnim.

* Dr Tomasz Sowiński - Katedra Prawa Finansowego, Wydział Prawa i Administracji, Uniwersytet Gdański.

1 T. Sowiński, Problematyka prawna i kompetencyjna gospodarki wodnej w Polsce, [w:] Stan gospodarki wodnej w Polsce, problematyka prawna i kompetencyjna (na przyktadzie dolnej Wisty), Kancelaria Senatu, „Zeszyty Zespołów Senackich” 2011, nr 8, s. 103-122. 
Przykładem działu administracji odzwierciedlającym w szczególnym stopniu powyższe problemy może być wspomniana już gospodarka wodna, która jest dziedziną interdyscyplinarną, a $\mathrm{w}$ realizację poszczególnych zadań bywa zainteresowanych wiele podmiotów. Inwestycje przeciwpowodziowe, regulacyjne i inne mogą być i są podejmowane często na znacznym obszarze, łączącym terytoria wielu gmin, powiatów, a często i województw. Nie do końca są jasne zasady współdziałania i łączenia środków finansowych podmiotów uczestniczących w realizacji takiego zadania oraz odpowiedzialności za podejmowane decyzje. Istnieje wprawdzie prawo dotyczące partnerstwa publiczno-prywatnego, ale często $\mathrm{w}$ przedsięwzięciach dotyczących gospodarki wodnej wszystkie podmioty uczestniczące w jego realizacji są publiczne ${ }^{2}$. Wsparciem dla realizacji zadań publicznych w tej dziedzinie byłoby prawo wspomagające takie przedsięwzięcia.

Pozwalam sobie zaproponować w niniejszym opracowaniu koncepcję wprowadzenia rozwiązań prawnych określonych jako Program Partnerstwa Publicznego (dalej: PPP). Proponowane określenie zasad współdziałania podmiotów publicznych, przede wszystkim ze sfery administracji centralnej i lokalnej, może mieć kluczowe znaczenie dla zdynamizowania działań w zakresie złożonych i realizowanych przez liczne podmioty, zwłaszcza publiczne, inwestycji czy też realizowania interdyscyplinarnych zadań wymagających współpracy różnych jednostek administracji.

W większości państw UE administracja publiczna posiada jasno sformułowane zasady działania i montażu środków pieniężnych - tak publicznych, jak i prywatnych. W przestrzeni finansów publicznych w Polsce można stwierdzić, że z pozoru nie ma szczególnych przeszkód do działań wielu podmiotów publicznych przy złożonych zadaniach i inwestycjach. Są jednak dwa podstawowe problemy związane z tą sferą, które uzasadniają wtrącenie zwrotu: „z pozoru”. Pierwszy to oczywiście brak środków na realizację wielu zadań państwa czy samorządu terytorialnego, a w niektórych dziedzinach, jak choćby w przypadku wspomnianej wyżej gospodarki wodnej, na większość zadań państwa. Drugi problem to dość „nieszczęśliwie” sformułowana treść ustawy z dnia 17 grudnia 2004 r. o odpowiedzialności za naruszenie dyscypliny finansów publicznych (dalej: u.o.n.d.f.p. $)^{3}$, zwłaszcza w ich kontekście braku jasnej, skierowanej do podmiotów publicznych formuły wykonywania przez nie swych zadań. Jak zauważono, można by wskazać w niektórych przypadkach takie formuły, ale najczęściej są

${ }^{2}$ K. Dmochowska, M. Gajda, J. Gille, C. Gołębiowski, J. Harmsen, I. Kotowska, M. Mańkowska, M. Mironowicz, M. Pluciński, J. Rekiel, T. Sowiński, T. Sturm, Program rozwoju infrastruktury transportu wodnego śródladowego w Polsce, cz. 2: Propozycja wieloletniego programu rozwoju infrastruktury transportu wodnego śródlądowego w Polsce, Warszawa-Rotterdam, lipiec 2011.

${ }^{3}$ Dz. U. z 2005 r. Nr 14, poz. 114 ze zm. Ustawa weszła w życie w dniu 1 lipca 2005 r. Wcześniej regulacje prawne z zakresu dyscypliny finansów publicznych były zawarte $\mathrm{w}$ ustawie z dnia 26 listopada 1998 r. o finansach publicznych, t.j. Dz. U. z 2003 r. Nr 15, poz. 148 ze zm. 
one żmudne, wymagające długiego okresu przygotowań, wielu zgód, zwłaszcza w przypadku administracji centralnej. Obawa urzędników przed konsekwencjami nawet nieświadomego naruszenia zasad dyscypliny finansów publicznych niejednokrotnie paraliżuje wszelkie działania i kończy żywot różnych inicjatyw, zanim zaczną przybierać stan możliwy do realizacji. Wskazanie jasnej i prostej formuły podejmowania podobnych inicjatyw niewątpliwie przyczyniłoby się do znacznego ożywienia działań podmiotów publicznych w zadaniach wymagających współdziałania wielu wykonawców, a w szczególności korzystania ze środków finansowych wielu podmiotów, zwłaszcza z omawianej sfery publicznej.

\section{Potrzeba i cel wprowadzenia projektowanych rozwiązań}

Prawo i problematyka kompetencji administracji publicznej jest zagadnieniem dotyczącym całego obszaru Rzeczypospolitej.

Zmiana (uzupełnienie) ustawy o finansach publicznych o dział zawierający nową instytucję sektora finansów publicznych - Program Partnerstwa Publicznego, powoływaną w celu realizacji konkretnych projektów, ma w założeniu umożliwić skuteczne współdziałanie administracji publicznej różnych szczebli i rodzajów w zakresie realizacji wspólnych inwestycji, montażu finansowego, wspólnego ubiegania się o środki pomocowe i innych działań niezbędnych do zarządzania skutecznego, sprawnego i zgodnego z ustawami o finansach publicznych ${ }^{4}$ oraz ustawą o odpowiedzialności za naruszenie dyscypliny finansów publicznych.

Proponowane rozwiązanie będzie oddziaływać (zgodnie z obecnym porządkiem prawnym) przede wszystkim na jednostki administracji publicznej szczebla centralnego i samorządowego, podmioty publiczne, społeczne i prywatne prowadzące działalność statutową, gospodarczą, administracyjną.

Wejście w życie zmian ustawy o finansach publicznych będzie miało pozytywny wpływ na funkcjonowanie sektora finansów publicznych. Przewiduje, że mogą one spowodować, iż wpływy do budżetu państwa będą większe z tego względu, że podejmie się realizację wielu złożonych i wymagających współpracy licznych jednostek administracji publicznej zadań, których do tej pory, ze względu na brak jasnych reguł takiego postępowania, nie podejmowano. Istotna zwłaszcza jest możliwość tzw. „montażu finansowego” - łączenia środków finansowych pochodzących od wielu podmiotów publicznych. Do tej pory wielu zadań nie można było realizować lub ich realizacja była złożona logistycznie i organizacyjnie, a także wymagająca podjęcia szeregu skomplikowanych i wątpliwych interpretacyjnie działań oraz decyzji administracyjnych, niosących ze sobą ryzyko naruszenia u.o.n.d.f.p. Istotnym powodem był także brak środków finansowych

${ }^{4}$ Ustawa z dnia 27 sierpnia 2009 r. o finansach publicznych, Dz. U. z 2009 r. Nr 157, poz. 1240, art. 9, p. 2). 
pozostających w dyspozycji poszczególnych podmiotów publicznych, co uniemożliwiało samodzielną realizację większych i bardziej kosztownych zadań.

Jasne zasady wspólnej realizacji zadań przez podmioty publiczne, dające im także możliwość łączenia posiadanych środków finansowych, rozwiążą oba wskazane wyżej problemy, to jest zarówno brak środków, jak i brak zasad współpracy oraz łączenia posiadanych zasobów finansowych, bez ryzyka naruszenia u.o.n.d.f.p. bądź konieczności „karkołomnych” i ryzykownych prawnie rozwiązań doraźnych, umożliwiających ich realizację. Zasadne zatem jest oczekiwanie utworzenia w związku z tym wielu nowych miejsc pracy. Restrukturyzacja działań administracji publicznej różnych szczebli i rodzajów przyczyni się też do optymalizacji zatrudnienia i oszczędności w tej sferze.

Dzięki wprowadzeniu w życie przepisów związanych z PPP nastąpi znacznie bardziej racjonalne i oszczędne wykorzystanie środków pieniężnych przeznaczonych na inwestycje w wielu dziedzinach, choćby wspominanej gospodarce wodnej, czyli np. rewitalizacji i utrzymaniu śródlądowych dróg wodnych, infrastruktury związanej z żeglugą i turystyką, zwiększenie stanu majątku narodowego (np. nowe centra multimodalne, elektrownie wodne, zbiorniki retencyjne). Należy także zwrócić uwagę na pozytywny aspekt, jakim będzie zmniejszenie wydatków budżetu związanych z wypłatą odszkodowań i naprawą skutków powodzi, które dzięki budowie infrastruktury nie nastąpią lub wystąpią w znacznie zmniejszonym rozmiarze. Redukcja strat związanych z powodziami jest bardzo kosztowna - ostatnia powódź z 2010 r. spowodowała wydatki związane z usuwaniem jej skutków w wysokości ok. 13 mld zt5.

Warto wspomnieć o wielu innych działaniach, jak wspólne prowadzenie i finansowanie zadań związanych z ochroną środowiska (np. budowa oczyszczalni ścieków, nowoczesnych wysypisk śmieci czy zakładów ich utylizacji). To także możliwość wspólnego prowadzenia interdyscyplinarnych, ponadregionalnych placówek oświatowych, placówek opieki zdrowotnej czy działań z zakresu zarządzania kryzysowego, a w tym związanych z możliwością wystąpienia różnorodnych zagrożeń i szkód - rezerw, magazynów specyficznych środków i sprzętu niezbędnych w różnego rodzaju akcjach wsparcia czy pomocy. Ich specyfika powoduje zasadność ich prowadzenia (utrzymywania) na szczeblu co najmniej regionalnym, a niejednokrotnie krajowym i realizacji przez bardzo liczne podmioty w wycinkowych dziedzinach wynikających z zakresu ich zadań i kompetencji, co jak do tej pory skutecznie uniemożliwiło powstanie takich placówek czy instytucji, bądź przyczyniło się do likwidacji istniejących.

${ }_{5}^{5}$ T. Sowiński, Załacznik Nr 5. Założenia do projektu ustawy o Gospodarce Wodnej oraz o zmianie ustawy o finansach publicznych, [w:] K. Dmochowska, M. Gajda, J. Gille, C. Gołębiowski, J. Harmsen, I. Kotowska, M. Mańkowska, M. Mironowicz, M. Pluciński, J. Rekiel, T. Sowiński, T. Sturm, Program rozwoju infrastruktury transportu wodnego śródladowego w Polsce, cz. 2: Propozycja wieloletniego programu..., s. 184-186. 
PPP umożliwi także dokonanie montaży finansowych pozwalających na skuteczne ubieganie się o znaczne środki z programów UE, które do tej pory były poza zasięgiem podmiotów publicznych i niepublicznych w Polsce.

\section{Propozycje rozstrzygnięć merytorycznych niezbędnych do opracowania projektu ustawy o zmianie ustawy o finansach publicznych}

Konieczność uporządkowania i uzupełnienia katalogu zasad finansowania zadań administracji publicznej, z kompetencjami umożliwiającymi skoordynowane zarządzanie i skuteczne wypełnienie zadań publicznych, zwłaszcza w większym zakresie, jest szczególną przesłanką do rozważenia zasadności wprowadzenia do polskiego porządku prawnego instytucji, jaką może stać się proponowany Program Partnerstwa Publicznego. Zmiana ustawy o finansach publicznych ma na celu uzupełnienie jej treści o nową formułę współpracy i prowadzenia zarówno wspólnych działań planistycznych i inwestycyjnych, jak i wspólnej aplikacji o środki europejskie $\mathrm{i}$ inne środki pozabudżetowe, w ramach porządku prawnego, a zwłaszcza prawno-finansowego RP.

\subsection{Zakres podmiotowy i przedmiotowy projektowanej ustawy o zmianie ustawy o finansach publicznych}

\subsubsection{Zakres podmiotowy}

Proponowana ustawa będzie oddziaływać (zgodnie z obecnym porządkiem prawnym) na jednostki administracji publicznej szczebla centralnego i samorządowego, administrację publiczną, a także podmioty publiczne, społeczne i prywatne prowadzące działalność statutową, gospodarczą, administracyjną w przestrzeni sektora finansów publicznych.

\subsubsection{Zakres przedmiotowy}

Projektowana ustawa zmienia (skupia) sposób zarządzania i wypełnienia zadań państwa przez jednostki sektora finansów publicznych, a zwłaszcza administrację publiczną.

Zmiana ustawy o finansach publicznych uzupełnia jej treść zarówno o nową formułę współpracy i prowadzenia wspólnych działań planistycznych i inwestycyjnych, jak i wspólną aplikację o środki europejskie i inne, jakim jest instytucja Programu Partnerstwa Publicznego. 


\subsection{Objaśnienia podstawowych określeń użytych w projekcie założeń}

Użyte w niniejszych założeniach określenia oznaczają:

- PPP - Program Partnerstwa Publicznego - jednostka organizacyjna sektora finansów publicznych tworzona w celu nadania prawno-finansowej formy współpracy podmiotów publicznych,

- ppp - Partnerskie Projekty Publiczne,

- PP-P - Partnerstwo Publiczno-Prywatne,

- JST - jednostka samorządu terytorialnego.

\subsection{Proponowana treść przepisów}

W ustawie o finansach publicznych wprowadza się następujące zmiany:

1) w art. 9 dopisuje się pkt 7) programy partnerstwa publicznego; zmienia się też numerację następnych punktów;

2) dopisuje się art. 28 o następującej treści ${ }^{6}$ :

1. Program Partnerstwa Publicznego (dalej: PPP) jest formą realizacji zadań publicznych przez podmioty publiczne państwowe i samorządowe.

2. Instrumentami realizacji Programu Partnerstwa Publicznego są Partnerskie Projekty Publiczne (dalej: ppp).

3. PPP ma na celu ściślejszą współpracę podmiotów publicznych w celu realizacji zadań publicznych oraz uproszczenie i ujednolicenie form owej współpracy, a zwłaszcza określenie procedur finansowych realizacji ppp.

4.1. Liderem projektu jest podmiot angażujący największe środki własne.

4.2. Jeśli środki własne lub pochodzące z UE przekraczają 50\% sumy środków w Projekcie, jest nim dysponent tych środków, na którego terytorium wykonywany jest projekt.

4.3. Zgodnie z zasadą pomocniczości, bez względu na liczbę i rangę podmiotów uczestniczących w Projekcie, Liderem powinna być jednostka samorządu terytorialnego (JST) najniższego szczebla, na której terenie będzie realizowany Projekt.

5.1. Jeśli projekt jest wykonywany na terenie kilku gmin jednego powiatu powiat, jeśli kilku powiatów jednego województwa - samorząd województwa, jeśli w kilku województwach - właściwy wojewoda lub województwo samorządowe realizujące większą część projektu i angażujące największe środki.

5.2. Wojewoda może zlecić wykonawstwo projektu samorządowi województwa.

6.1. Nad prawidłowością realizacji ppp czuwa Rada złożona z przedstawicieli podmiotów biorących w nim udział oraz właściwego (p. 8) organu nadzorującego jego wykonanie.

${ }^{6}$ Jest to jedynie zarys propozycji, który niewątpliwie wymaga dopracowania, ale odzwierciedla on założenia, sens i cel koncepcji. 
6.2. Radzie przewodniczy i zwołuje ją przedstawiciel Lidera ppp, który odpowiada także za właściwą organizację pracy Rady.

6.3. Radę zwołuje przewodniczący nie rzadziej niż raz na kwartał lub na wniosek połowy członków Rady bądź przedstawiciela organu nadzoru.

6.4. Zasady działania, zadania i obowiązki Rady są określone w zarządzeniu, o którym mowa w p. 10.4.

7.1. Poszczególne podmioty uczestniczące w PPP mogą proponować montaż finansowy swojej części wkładu finansowego do ppp angażujący także środki pochodzące z kredytu, pożyczki, obligacji (w przypadku samorządu), a także od podmiotów prywatnych, jednakże ponoszą one pełną odpowiedzialność za zaangażowane środki przed pozostałymi partnerami projektu, dla których są jedynym podmiotem partnerskim.

7.2. Wszelkie pozostałe relacje $\mathrm{z}$ innymi podmiotami uczestniczącymi w montażu finansowym dotyczą jedynie partnera, który go dokonuje.

7.3. Środki angażowane przez każdego z partnerów w budżet projektu są traktowane jako jego środki własne i nie powodują dla pozostałych partnerów żadnych innych zobowiązań, poza wynikającymi z projektu.

8. Nadzór nad właściwym wykonywaniem ppp oraz z zakresu dyscypliny finansów publicznych sprawuje właściwy miejscowo wojewoda, a jeśli realizacja PPP ma miejsce na terenie więcej niż jednego województwa - minister rozwoju regionalnego.

9. Spory kompetencyjne, w ramach realizowanego PPP, na terenie województwa rozstrzyga właściwy miejscowo wojewoda, a jeśli realizacja PPP ma miejsce na terenie więcej niż jednego województwa - minister rozwoju regionalnego.

10.1. Rejestr wszystkich PPP prowadzi minister rozwoju regionalnego.

10.2. Lider ppp w ciągu 14 dni od jego zawiązania podaje określone w zarządzeniu dane dotyczące PPP i ppp do podmiotu sprawującego zgodnie z p. 8 nadzór nad ppp oraz do ministra rozwoju regionalnego.

10.3. Określone w zarządzeniu, o którym mowa w p. 10.2, dane dotyczące zasad finansowania ppp jego lider podaje do wiadomości ministra właściwego do spraw finansów publicznych.

10.4. Zarządzenie, o którym mowa w p. 10.2, zostanie wydane przez ministra właściwego do spraw finansów publicznych, w uzgodnieniu z ministrem rozwoju regionalnego.

11. PPP może być partnerem PP-P7.

Szczegółowe rozwiązania prawne proponuje się jako nową formę organizacyjno-prawną jednostek sektora finansów publicznych, będącą dodatkowym artykułem ustawy o finansach publicznych. Z uwagi na to, że mogą być one przydatne dla działań podmiotów publicznych w wielu jednostkach różnych szczebli,

${ }^{7}$ T. Sowiński, Załacznik Nr 5. Założenia do projektu ustawy o Gospodarce Wodnej..., s. $181-196$. 
rodzajów i specjalności administracji publicznej, zasadne jest zawarcie ich w ustawie o finansach publicznych, gdyż w ten sposób proponowana instytucja prawno-finansowa, jaką może być PPP, mogłaby mieć szerokie zastosowanie.

Minister właściwy do spraw finansów publicznych w porozumieniu z ministrem właściwym do spraw rozwoju regionalnego oraz ministrem właściwym do spraw administracji winien określić w drodze rozporządzenia sposób prowadzenia rejestru PPP i rozwiązań szczególnych, np. zakres odpowiedzialności rzeczowej i majątkowej uczestników PPP, a zwłaszcza podmiotów prowadzących poszczególne projekty.

Podmioty uczestniczące w PPP określone w pkt 3.3.3 niniejszych założeń podlegają zasadom odpowiedzialności administracyjnej, karnej, odpowiedzialności za naruszenie dyscypliny finansów publicznych, karno-skarbowej.

\section{Ocena przewidywanych skutków społeczno-gospodarczych}

\subsection{Podmioty, na które oddziałuje projektowana regulacja}

Podmioty te zostały wymienione w pkt 3.1.1 niniejszego artykułu.

\subsection{Wpływ regulacji na:}

\subsubsection{Sektor finansów publicznych, w tym budżet państwa i budżety jednostek samorządu terytorialnego}

Wejście w życie ustawy o zmianie ustawy o finansach publicznych będzie pozytywnie oddziaływać na funkcjonowanie sektora finansów publicznych. Przewiduje się, że wpływy do budżetu państwa będą większe z tego względu, że podejmie się realizację PPP $\mathrm{w}$ wielu zadaniach publicznych, które do tej pory, ze względów opisanych wcześniej, pozostawały poza sferą możliwości skutecznego działania administracji publicznej, a to umożliwi m.in. utworzenie wielu nowych miejsc pracy. Restrukturyzacja działań administracji publicznej oraz umożliwienie finansowania wspólnych jej zadań przyczyni się do optymalizacji zatrudnienia i oszczędności także w tej dziedzinie.

Dzięki wprowadzeniu w życie przepisów związanych z PPP nastąpi znacznie bardziej racjonalne i oszczędne wykorzystanie środków pieniężnych przeznaczonych na inwestycje i realizację zadań publicznych, zwłaszcza o większym rozmiarze i stopniu złożoności oraz $\mathrm{w}$ wielu podmiotach podejmujących się wspólnej ich realizacji.

PPP umożliwi także dokonanie montaży finansowych pozwalających na skuteczne ubieganie się o znaczne środki z programów UE, które do tej pory były poza zasięgiem podmiotów publicznych, zwłaszcza jednostek samorządu tery- 
torialnego, a także podmiotów niepublicznych w Polsce. Zwiększona liczba podmiotów rejestrujących działalność gospodarczą w różnych dziedzinach gospodarki w Polsce to także zwiększone wpływy podatku dochodowego od osób prawnych do budżetu państwa i budżetów JST oraz w konsekwencji z tytułu podatku dochodowego od osób fizycznych, uzyskane od pracowników zatrudnionych na nowych miejscach pracy.

\subsubsection{Rynek pracy}

W związku z przewidywanym ożywieniem w wielu sektorach polskiej gospodarki i sfery usług publicznych, co zostało opisane szerzej w pkt 2, uważa się, że przyczyni się to do stopniowego wzrostu zatrudnienia w rozwijanych dziedzinach, ale i przez sektory pokrewne. Poprawiająca się sytuacja ekonomiczna dawałaby szansę na stopniowe ożywienie sektorów komplementarnych i sektora usług publicznych, co również wiązałoby się z powstaniem nowych miejsc pracy. W samej tylko gospodarce wodnej, która jest w treści niniejszego opracowania podawana jako dobry przykład na zasadność wprowadzenia PPP i jako sektor szczególnie oczekujący takich rozwiązań, przyczyniłaby się do ożywienia sektora polskiego transportu śródlądowego, a to z kolei wpłynie na stopniowy wzrost zatrudnienia marynarzy i pracowników obsługi przez polskich armatorów, a także przez sektory pokrewne, a zwłaszcza branżę turystyczną. Poprawiająca się sytuacja ekonomiczna armatorów dawałaby szansę na stopniowe ożywienie sektorów komplementarnych do żeglugi śródlądowej, takich jak np. przemysł portowy i stoczniowy czy szkolnictwo, co również wiązałoby się z powstaniem nowych miejsc pracy. Budowa centrów multimodalnych, modernizacja śluz, portów, torów wodnych, a następnie ich obsługa i utrzymanie to kolejne miejsca pracy. Oddzielnym, potężnym działem zapewniającym miejsca pracy, znaczne stałe dochody oraz zwiększenie udziału Polski w sektorze energii odnawialnej w ramach zobowiązań wynikających z członkostwa w Unii Europejskiej, a co za tym idzie także oszczędności wynikające ze zmniejszenia opłat związanych z ochroną środowiska jest energetyka wodna.

Podobne skumulowane efekty mogą być zauważalne także w innych dziedzinach do tej pory ,zaniedbywanych” przez administrację publiczną, ze względów opisanych wcześniej, jako argumenty za wprowadzeniem PPP.

\subsubsection{Rozwój regionalny}

Projektowana ustawa o zmianie ustawy o finansach publicznych będzie miała pozytywny wpływ na sytuację i rozwój regionalny. W dziedzinie gospodarki wodnej zostanie ożywiona przede wszystkim żegluga śródlądowa, a z nią turystyka i infrastruktura usługowa. Zwiększenie liczby miejsc pracy to także większe wpływy do budżetów JST z działalności gospodarczej, a także z podatków dochodowych. 


\section{Podsumowanie}

Propozycja nowej formy wspólnego prowadzenia projektów inwestycyjnych zwiększy możliwość absorbcji środków z funduszy europejskich i przyczyni się do ożywienia gospodarczego także $w$ innych branżach, np. budownictwie lądowym i wodnym, sferze usług publicznych i usługach, w ochronie środowiska, energetyce odnawialnej, rolnictwie. Rolnictwo może skorzystać na przywróceniu właściwych form i rozmiaru melioracji, zarzuconych od wielu lat z powodu braku środków i realizowanych jedynie akcyjnie oraz w niewielkim zakresie w stosunku do potrzeb. Podobnie rzecz się ma $\mathrm{w}$ aspekcie bezpieczeństwa przeciwpowodziowego, a zupełnie brakuje działań w zakresie przeciwdziałania występowaniu skutków suszy. Oddzielnym problemem o istotnym, a wręcz kluczowym znaczeniu dla państwa jest infrastruktura transportowa, zwłaszcza drogowa, która z charakteru przekracza nie tylko granice, ale i możliwości finansowe gmin, powiatów czy województw, a nawet państwa.

Niemoc Polski odnośnie do sieci transportowej TENT, korytarza transportowego TINA, MDW E-40 czy MDW E-70, nieprzystąpienie do konwencji AGN, brak choćby jednej ukończonej autostrady, linie kolejowe czy urządzenia przeciwpowodziowe sięgające na niektórych obszarach kraju rozwiązaniami technicznymi do okresu zaborów to przykłady aż nadto uzasadniające konieczność podjęcia wszelkich działań i przyjęcia wszelkich możliwych rozwiązań prawnych, w tym prawno-finansowych, które mogą przynajmniej w niewielkim stopniu przyczynić się do ożywienia gospodarczego, zwiększenia liczby i jakości wykonywanych zadań publicznych, zwiększenia komfortu życia, choć na razie należy raczej mówić o zmniejszeniu uciążliwości życia mieszkańców oraz zapewnieniu im miejsc pracy do 67. roku życia.

Wyrażam przekonanie, iż takim pożądanym instrumentem, mogącym przyczynić się do ożywienia gospodarczego i zwiększenia możliwości administracji publicznej w zakresie wykonywania zadań państwa, może być proponowana w niniejszych rozważaniach koncepcja Programu Partnerstwa Publicznego. 